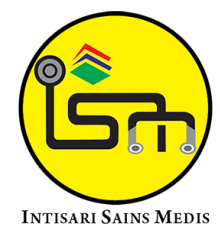

Published by Intisari Sains Medis

\section{Faktor-faktor yang berhubungan dengan kinerja pegawai administrasi rumah sakit di era new normal}

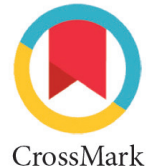
Ellen Deivi Tamuntuan ${ }^{1 *}$, Starry Homenta Rampengan ${ }^{1}$, Oksfriani Jufri Sumampouw ${ }^{1}$,
Aaltje Ellen Manampiring ${ }^{1}$

\section{ABSTRACT}

Background: Administrative employees as nonhealth workers in hospitals must provide excellent service so that organizational goals can be achieved, even though there are changes in the employee work system in this new normal era. Employee performance can be determined by factors related to performance, namely work discipline, motivation, leadership style, and work environment. This study aims to analyze the factors related to the performance of the administrative staff of the Ratatotok Buyat Central General Hospital (RSUP) in the new normal era.

Methods: This study is an analytical study with a cross-sectional approach. This research was conducted at Ratatotok Buyat Hospital in May-June 2021. The research sample consisted of 50 respondents. The research instrument is a questionnaire that has been tested for validity and reliability-research data obtained through closed interviews. The data obtained were analyzed by univariate, bivariate, and multivariate. We used bivariate analysis using Pearson correlation

test and multivariate analysis using multiple linear regression, with $=0.05$.

Results: The results of this study indicate that the majority of the respondents are female (58\%), aged 2035 years $(62 \%)$, have undergraduate education $(72 \%)$, and have worked 6-10 years (52\%). In addition, the results obtained in this study are work discipline, work motivation, leadership style, and work environment, $p$ $<0.05$. The most influential factor on the performance of the administrative staff of Ratatotok Buyat Hospital is the work discipline variable $(B=0.520)$. This study also obtained an R-square value of 0.661 , which means work discipline, work motivation, leadership style, and work environment influence $66.1 \%$ on performance.

Conclusion: There is a significant and positive relationship between work discipline, work motivation, leadership style, and work environment with the performance of administrative employees. The most influential variable is work discipline.

Keywords: Performance; Administrative Officer; Hospital; New Normal Era.

Cite This Article: Tamuntuan, E.D., Rampengan, S.H., Sumampouw, O.J., Manampiring, A.E. 2021. Faktor-faktor yang berhubungan dengan kinerja pegawai administrasi rumah sakit di era new normal. Intisari Sains Medis 12(2): 736-742. D01: 10.15562/ism.v12i2.1092

'Program Studi Magister IImu Kesehatan Masyarakat Program Pascasarjana Universitas Sam Ratulangi;

*Korespondensi:

Ellen Deivi Tamuntuan;

Program Studi Magister Ilmu Kesehatan Masyarakat, Program Pascasarjana, Universitas Sam Ratulangi; ellen@gmail.com
Juni 2021. Sampel penelitian berjumlah 50 responden. Instrumen penelitian yaitu kuesioner yang telah diuji validitas dan reliabilitas. Data penelitian diperoleh melalui wawancara tertutup. Data yang diperoleh dianalisis secara univariat, bivariat dan multivariat. Analisis bivariat menggunakan uji korelasi pearson dan analisis multivariat menggunakan uji regresi linear berganda, dengan $a=0,05$.

Hasil: Hasil penelitian ini menunjukkan bahwa responden paling banyak berjenis kelamin perempuan (58\%), berusia 20-35 tahun (62\%), berpendidikan sarjana/S1 (72\%) dan masa kerja 6-10 tahun (52\%). Selain itu hasil yang diperoleh dalam penelitian ini yaitu disiplin kerja, motivasi kerja, gaya kepemimpinan dan lingkungan kerja nilai $p<0,05$. Faktor yang paling 
berpengaruh terhadap kinerja pegawai administrasi RSUP Ratatotok Buyat yaitu variabel disiplin kerja $(B=0,520)$. Diperoleh juga dalam penelitian ini nilai $R^{2}$ sebesar 0,661 yang berarti disiplin kerja, motivasi kerja, gaya kepemimpinan dan lingkungan kerja memiliki pengaruh sebesar $66,1 \%$ terhadap kinerja.
Kesimpulan: Terdapat hubungan bermakna dan positif antara disiplin kerja, motivasi kerja, gaya kepemimpinan dan lingkungan kerja dengan kinerja pegawai administrasi. Variabel yang paling berpengaruh yaitu disiplin kerja.

Kata kunci: Kinerja; Pegawai Administrasi; Rumah Sakit; Era New Normal.

Sitasi Artikel ini: Tamuntuan, E.D., Rampengan, S.H., Sumampouw, 0.J., Manampiring, A.E. 2021. Faktor-faktor yang berhubungan dengan kinerja pegawai administrasi rumah sakit di era new normal. Intisari Sains Medis 12(2): 736-742. D01: 10.15562/ism.v12i2.1092

\section{LATAR BELAKANG}

Sumber daya manusia pada rumah sakit sangat kompleks, ada berbagai jenis profesi yang saling berinteraksi, baik tenaga kesehatan maupun tenaga non kesehatan. ${ }^{1}$ Untuk mencapai rumah sakit yang mampu memberikan pelayanan prima dan sesuai tujuan organisasi, diperlukan sumber daya manusia yang berkualitas dan berkinerja baik. ${ }^{2}$ Kinerja pegawai dipengaruhi oleh faktor internal dan ekternal. Penelitian di Rumah Sakit Umum Daerah (RSUD) Pelalawan, membuktikan bahwa motivasi kerja sebagai bentuk pemberian dorongan kepada pegawai penting dilakukan karena dapat meningkatkan kinerja pegawai. ${ }^{3}$ Penelitian oleh Hayati, dkk, menemukan bahwa disiplin berhubungan dengan kinerja. ${ }^{4}$ Ali dan Agustian dalam penelitiannya menemukan bahwa gaya kepemimpinan memiliki hubungan yang positif dan juga signifikan dengan kinerja pegawai. ${ }^{5}$ Penelitian oleh Pamungkas dan Widowati menemukan bahwa adanya sarana dan prasarana yang mendukung dalam pelaksanaan tugas dapat meningkatkan kinerja artinya semakin baik lingkungan kerja maka dapat meningkatkan kinerja pegawai. ${ }^{6}$

Rumah Sakit Umum Pusat (RSUP) Ratatotok Buyat merupakan salah satu rumah sakit rujukan Covid-19 di wilayah kabupaten Minahasa Tenggara dan sekitarnya. Sumber daya manusia pada bagian administrasi sebanyak 51 orang. Rumah Sakit Umum Pusat Ratatotok Buyat sebelum pandemi Covid-19, menerapkan apel pagi dilaksanakan tiga kali dalam satu minggu, presensi pegawai menggunakan fingerprint, jam kerja sebanyak 7,5 jam/ hari, 37,5 jam/minggu dan 150 jam/bulan.
Pada masa pandemi Covid-19, sistem dan kegiatan terkait pekerjaan pegawai administrasi mengalami perubahan. Hal itu dilakukan untuk memutuskan penyebaran Covid-19 di lingkungan RSUP Ratatotok Buyat. Memasuki era new normal kebijakan yang diterapkan sesuai edaran Sekretaris Jenderal Kementerian Kesehatan dan Direktur RSUP Ratatotok Buyat yaitu pegawai kembali bekerja seperti biasa namun harus menjalankan protokol kesehatan, memakai masker, sering mencuci tangan menggunakan sabun dengan air mengalir, menjaga jarak, dan menghindari kerumunan. Work from home (WFH) berlaku hanya bagi PNS yang terpapar Covid-19 dengan status orang tanpa gejala. Jam kerja diberlakukan sama seperti sebelum masa pandemi Covid-19 yaitu 7,5 jam/hari, 5 hari dalam satu minggu (37,5 jam). Kemudian sudah tidak ada kegiatan apel pagi, dan presensi pegawai menggunakan daftar hadir manual.

Berdasarkan observasi langsung di bagian administrasi RSUP Ratatotok Buyat, kebijakan yang dilakukan di era new normal sedikit banyak berdampak pada kinerja pegawai. Sejak adanya pandemi hingga era new normal saat ini, banyak pegawai yang kurang disiplin. Interaksi antar pegawai bahkan dengan pimpinan terbatas karena harus menjaga jarak. Tidak ada lagi kegiatan rekreatif, tidak ada kegiatan di luar daerah seperti pelatihan-pelatihan yang dapat memberikan semangat kerja bagi pegawai. Hal-hal ini tampaknya menjadikan pegawai kurang termotivasi dalam bekerja. Pemantauan dari atasan terhadap kerja pegawai kurang optimal. Lingkungan kerja khususnya di bagian administrasi RSUP Ratatotok Buyat masih belum baik seperti adanya gangguan listrik dan internet, ruangan yang tidak diatur dengan baik sehingga berisiko terjadinya penularan. Hal-hal inilah yang diduga bisa menyebabkan menurunnya kinerja pegawai, sehingga perlu dilakukannya kajian mendalam menganalisis faktorfaktor yang berhubungan dengan kinerja pegawai administrasi Rumah Sakit Umum Pusat (RSUP) Ratatotok Buyat di era new normal.

\section{METODE}

Penelitian ini merupakan penelitian kuantitatif yang bersifat survei analitik dengan pendekatan potong lintang atau cross sectional study. Penelitian ini dilaksanakan di RSUP Ratatotok Buyat pada Mei-Juni 2021. Jumlah populasi 51 responden. Teknik pengambilan sampel yakni total sampling. Sampel penelitian berjumlah 50 responden (1 orang sebagai peneliti). Data dalam peneltian ini dikumpulkan melalui kuesioner yang diisi oleh masing-masing responden. Adapun data yang dikumpulkan dalam penelitian ini yaitu jenis kelamin, usia, tingkat pendidikan, masa kerja, kinerja kerja, disiplin kerja, motivasi kerja, gaya kepemimpinan, dan lingkungan kerja. Analisis data dilakukan secara univariat, bivariat dan multivariat dengan menggunakan aplikasi SPSS 26.

\section{HASIL}

\section{Karakteristik Responden dan Analisis Univariat}

Berdasarkan karakteristik responden dapat dilihat bahwa responden terbanyak dalam penelitian ini yaitu berjenis kelamin 
perempuan berjumlah 29 responden (58\%) dan paling sedikit berjenis kelamin laki-laki sebanyak 21 responden (42\%), kelompok usia 20-35 tahun yang terbanyak berjumlah 31 responden (62\%) dan yang paling sedikit yaitu 19 responden dengan kelompok usia 36-55 tahun (38\%), terdapat 36 responden dengan tingkat pendidikan S1 (72\%), 8 responden (16\%) pendidikan SMA, 5 responden (10\%) berpendidikan Diploma Tiga dan yang paling sedikit yaitu responden dengan pendidikan S2 berjumlah 1 orang (2\%), masa kerja yang terbanyak pada rentan waktu usia kerja 6-10 tahun sebanyak 26 responden (52\%), 20 responden dengan masa kerja 1-5 tahun (40\%) dan yang paling sedikit responden dengan masa kerja lebih dari 10 tahun berjumlah 4 responden (8\%).

Kinerja kategori baik sebanyak 25 responden (50\%), 24 responden (48\%) termasuk dalam kategori kinerja cukup dan paling sedikit responden dengan kinerja kurang sebanyak 1 responden (2\%), responden dengan disiplin kerja kategori cukup berjumlah 29 responden (58\%), 20 responden (40\%) memiliki disiplin kerja kategori baik dan paling sedikit yakni 1 responden $(2 \%)$ yang termasuk dalam kategori disiplin kerja kurang, motivasi kerja tergolong baik sebanyak 32 responden (64\%) sedangkan paling sedikit responden tergolong motivasi kerja cukup sebanyak 18 responden (36\%), gaya kepemimpinan dikatakan baik oleh 29 responden (58\%) sedangkan 21 responden lainnya (42\%) mengatakan gaya kepemimpinan berada pada kategori cukup, lingkungan kerja digolongkan baik oleh 27 responden (54\%), digolongkan cukup oleh 22 responden (44\%) sedangkan paling sedikit responden menyatakan berada pada lingkungan kerja kurang yakni sebanyak 1 responden (2\%).

\section{Hubungan Antar Variabel Hubungan Disiplin Kerja dengan Kinerja}

Berdasarkan uji korelasi pearson, hubungan antara disiplin kerja dengan kinerja diperoleh nilai $r=0,738$. Hal ini menunjukkan terdapat hubungan kuat dan positif antara disiplin kerja dengan kinerja pegawai administrasi RSUP Ratatotok Buyat di era new normal. Selain itu diperoleh nilai $\mathrm{p}<0,05$ yang menunjukkan adanya hubungan bermakna antara disiplin kerja dengan kinerja. Hal ini ditandai dengan sebesar $40 \%$ responden yang memiliki disiplin kerja baik dengan kinerja yang baik, $10 \%$ responden dengan disiplin kerja cukup dan memiliki kinerja baik, $48 \%$ responden memiliki kinerja cukup dengan disiplin kerja cukup dan terdapat $2 \%$ responden yang memiliki kinerja kurang dengan disiplin kerja kurang.

Penelitian ini sejalan dengan penelitian yang dilakukan oleh Hulwani, dkk, tentang hubungan kompensasi dan disiplin dengan kinerja perawat unit pelayanan khusus di Rumah Sakit Umum Daerah Kota Langsa. Penelitian ini bersifat survey dengan pendekatan cross sectional dengan jumlah responden 55 orang, menunjukkan bahwa nilai $\mathrm{p}<0,05$, yang berarti terdapat hubungan yang signifikan antara disiplin kerja dengan kinerja perawat unit pelayanan khusus di Rumah Sakit Umum Daerah Kota Langsa. ${ }^{7}$ Hasil penelitian lain yang sejalan dengan penelitian ini yaitu penelitian dari Indriyani, dkk, tentang pengaruh gaya kepemimpinan dan disiplin kerja terhadap kinerja karyawan Rumah Sakit Taman Harapan Baru yang menunjukkan bahwa disiplin kerja berpengaruh signifikan terhadap kinerja karyawan di Rumah Sakit Taman Harapan Baru. ${ }^{8}$

\section{Hubungan Motivasi dengan Kinerja}

Berdasarkan uji korelasi pearson, hubungan antara motivasi dengan kinerja diperoleh nilai $r=0,632$. Hal ini menunjukkan terdapat hubungan kuat dan positif antara motivasi dengan kinerja pegawai administrasi RSUP Ratatotok Buyat di era new normal. Selain itu diperoleh nilai $\mathrm{p}<0,05$ yang menunjukkan adanya hubungan bermakna antara motivasi dengan kinerja. Dari total 50 responden, terdapat $48 \%$ responden dengan motivasi kerja yang baik memiliki kinerja baik, $16 \%$ responden dengan kategori motivasi kerja baik mempunyai kinerja cukup, 2\% responden memiliki motivasi cukup dengan kinerja baik dan $32 \%$ responden yang memiliki kinerja cukup dengan kategori motivasi cukup serta $2 \%$ responden dengan motivasi kurang memiliki kinerja kurang.
Hasil penelitian ini sama dengan hasil penelitian dari Ariko dan Sumarni (2021) tentang hubungan motivasi kerja dengan kinerja perawat di ruang rawat inap RSUD Ajibarang. Pada hasil penelitian diperoleh nilai $\mathrm{p}<0,05$ yang menunjukkan bahwa terdapat hubungan yang signifikan antara motivasi dengan kinerja perawat di ruang rawat inap RSUD Ajibarang.' Penelitian yang sama dilakukan terhadap perawat di ruang rawat inap UPTD RSUD Bitung, jenis penelitian yaitu survei analitik dengan pendekatan cross sectional dengan jumlah 62 responden yang menunjukkan bahwa terdapat hubungan antara motivasi dengan kinerja perawat, dengan nilai $\mathrm{p}<0,05 .^{10}$

\section{Hubungan Gaya Kepemimpinan dengan Kinerja}

Berdasarkan uji korelasi pearson, hubungan antara gaya kepemimpinan dengan kinerja diperoleh nilai $r=0,467$. Hal ini menunjukkan terdapat hubungan sedang dan positif antara disiplin kerja dengan kinerja pegawai administrasi RSUP Ratatotok Buyat di era new normal. Selain itu diperoleh nilai $\mathrm{p}<0,05$ yang menunjukkan adanya hubungan bermakan antara gaya kepemimpinan dengan kinerja. Responden yang mengatakan bahwa gaya kepemimpinan tergolong baik dan memiliki kinerja baik $40 \%$, gaya kepemimpinan baik dengan kinerja cukup 18\%, memiliki kinerja baik dengan gaya kepemimpinan cukup sebesar $10 \%$, dan terdapat $30 \%$ responden yang menggolongkan gaya kepemimpinan dalam kategori cukup memiliki kinerja cukup serta $2 \%$ responden mengatakan gaya kepemimpinan termasuk kategori cukup dengan kinerja kurang.

Penelitian ini sejalan dengan penelitian yang dilakukan oleh Indriyani mengenai pengaruh gaya kepemimpinan dan disiplin kerja terhadap kinerja karyawan Rumah Sakit Taman Harapan Baru Bekasi. ${ }^{8}$ Hasil penelitian menunjukkan bahwa gaya kepemimpinan berpengaruh secara signifikan terhadap kinerja karyawan. Penelitian di Rumah Sakit Muhammadiyah Metro juga menyatakan bahwa ada pengaruh positif antara gaya kepemimpinan dengan kinerja pegawai. ${ }^{5}$ 


\section{Hubungan Lingkungan Kerja dengan Kinerja}

Berdasarkan uji korelasi pearson, hubungan antara lingkungan kerja dengan kinerja diperoleh nilai $\mathrm{r}=0,535$. Hal ini menunjukkan terdapat hubungan sedang dan positif antara disiplin kerja dengan kinerja pegawai administrasi RSUP Ratatotok Buyat di era new normal. Selain itu diperoleh nilai $\mathrm{p}<0,05$ yang menunjukkan adanya hubungan bermakna antara lingkungan kerja dengan kinerja. Responden yang menyatakan bahwa lingkungan kerja tergolong baik dan memiliki kinerja baik sebanyak 50\%, lingkungan kerja dikatakan baik dengan kinerja cukup dari responden sebesar $4 \%$, kinerja cukup dengan lingkungan kerja digolongkan cukup 42\%, lingkungan kerja cukup dengan kinerja kurang $2 \%$ dan terdapat $2 \%$ responden yang menggolongkan lingkungan kerja pada kategori kurang memiliki kinerja cukup.

Hasil penelitian ini sejalan dengan penelitian tentang faktor-faktor yang berhubungan dengan kinerja perawat di unit rawat inap RSUD Ungaran Kabupaten Semarang. Penelitian ini merupakan penelitian kuantitatif, desain cross sectional dengan jumlah sampel 87 responden. Hasil penelitian yang dilakukan memperoleh nilai $\mathrm{p}<0,05$ yang berarti terdapat hubungan antara lingkungan kerja dengan kinerja perawat. ${ }^{11}$ Sejalan dengan itu, hasil penelitian tentang faktor-faktor yang mempengaruhi kinerja perawat Rumah Sakit Pabatu di Serdang Berdagai memperoleh nilai $\mathrm{p}<0,05$, artinya lingkungan kerja berpengaruh signifikan terhadap kinerja perawat. ${ }^{12}$

\section{Analisis Multivariat}

Tabel 1 menunjukkan hasil analisis multivariat dengan menggunakan uji regresi logistik pada variabel disiplin kerja, motivasi, gaya kepemimpinan dan lingkungan kerja terlihat bahwa terdapat 3 variabel yang berpengaruh terhadap kinerja yaitu variabel disiplin kerja dengan nilai $\mathrm{p}=0,000$, motivasi kerja dengan nilai $\mathrm{p}=0,041$ dan lingkungan kerja dengan nilai $\mathrm{p}=0,046$. Faktor yang paling berpengaruh terhadap kinerja pegawai administrasi RSUP Ratatotok Buyat yaitu variabel disiplin kerja $(B=0,520)$. Selain itu, diperoleh nilai $\mathrm{R}^{2}$ sebesar 0,661 yang

Tabel 1. Hasil uji regresi logistik variabel.

\begin{tabular}{|c|c|c|c|c|}
\hline Variabel & Koefisien regresi & Beta (B) & $\mathbf{t}_{\text {hitung }}$ & Sig. \\
\hline Konstanta & 3.676 & & & \\
\hline Disiplin $\left(\mathrm{X}_{1}\right)$ & 0.960 & 0.520 & 4.914 & 0.000 \\
\hline Motivasi $\left(\mathrm{X}_{2}\right)$ & 0.153 & 0.239 & 2.108 & 0.041 \\
\hline Gaya kepemimpinan $\left(\mathrm{X}_{3}\right)$ & 0.013 & 0.022 & 0.205 & 0.838 \\
\hline Lingkungan kerja $\left(\mathrm{X}_{4}\right)$ & 0.300 & 0.216 & 2.055 & 0.046 \\
\hline Fhitung & $=21,912$ & & & \\
\hline Rsquare & $=0,661$ & & & \\
\hline
\end{tabular}

berarti disiplin kerja, motivasi kerja, gaya kepemimpinan dan lingkungan kerja memiliki pengaruh sebesar $66,1 \%$ dengan kinerja.

\section{PEMBAHASAN}

\section{Karakteristik Responden}

Hasil penelitian menunjukkan bahwa responden paling banyak berjenis kelamin perempuan (58\%), berusia 20-35 tahun (62\%), berpendidikan sarjana/S1 (72\%) dan masa kerja 6-10 tahun (52\%). \%). Hasil penelitian ini menunjukkan bahwa tidak ada perbedaan yang konsisten terkait keterampilan dalam pekerjaan, kemampuan dalam menyelesaikan masalah serta dorongan kompetitif dalam bekerja antara laki-laki dan perempuan. Responden dalam penelitian ini masuk pada kelompok umur produktif. Usia dapat mempengaruhi kinerja seseorang. Meningkatnya usia maka akan diikuti dengan kinerja seseorang semakin menurun, namun dilain pihak usia seseorang dapat menunjukkan kedewasaan seseorang. Hal ini merupakan salah satu dari faktor yang dapat mempengaruhi kemampuan, pengetahuan, tanggung jawab dalam bertindak serta berpikir bahkan dalam mengambil keputusan. Hasil penelitian ini menunjukkan bahwa sebagian besar sudah berpendidikan sarjana. Hal ini menyebabkan kemampuan kerja seseorang semakin baik. Semakin tinggi tingkat pendidikan seseorang maka semakin tinggi pula kemampuan bekerja meskipun dengan tingkat kesulitan yang tinggi, serta semakin tinggi pula rasa tanggung jawab terhadap pekerjaan. ${ }^{13}$ Sebagian besar responden dalam penelitian ini telah bekerja selama 6-10 tahun. Hal ini menunjukkan bahwa para responden telah masuk pada masa kerja yang cukup lama, mereka sudah terbiasa dan beradaptasi dengan tempat kerjanya. Masa kerja menunjuk pada lama waktu seseorang melaksanakan tanggung jawab pekerjaannya. Semakin lama seseorang bekerja maka idealnya kemampuan kerjanya pun semakin meningkat karena semakin menguasai pekerjaannya. ${ }^{14}$

\section{Hubungan Disiplin Kerja dengan Kinerja}

Hubungan antara disiplin kerja dengan kinerja diperoleh nilai $\mathrm{r}=0,738$ dan nilai $\mathrm{p}<0,05$. Hal ini menunjukkan bahwa hubungan antara disiplin kerja dengan kinerja mempunyai hubungan yang kuat dan berpola positif artinya semakin baik disiplin kerja pegawai maka akan diikuti oleh kinerja yang semakin meningkat. Selain itu, ada hubungan bermakna antara disiplin kerja dengan kinerja.

Kategori nilai disiplin kerja pegawai menunjukkan bahwa disiplin pegawai masih belum sesuai harapan rumah sakit karena 58\% pegawai memiliki disiplin kerja dalam kategori cukup, bahkan masih ada pegawai yang memiliki disiplin kerja kurang (2\%). Kehadiran yang merupakan indikator mendasar dalam mengukur kedisiplinan masih sering diabaikan oleh responden. Hal ini sesuai dengan distribusi frekuensi jawaban responden yakni berdasarkan persepsi responden terdapat $24 \%$ dan berdasarkan penilaian atasan langsung terdapat $36 \%$ responden yang masih mengabaikan indikator kehadiran. Pada masa pandemi termasuk di era new normal ini presensi pegawai hanya menggunakan presensi manual dan tidak menggunakan finger print dengan tujuan untuk memutus rantai penularan Covid-19, namun hal ini memberikan peluang bagi pegawai untuk tidak mematuhi ketentuan jam kerja. Adanya pembatasan-pembatasan seperti menjaga 
jarak, menghindari kerumunan, interaksi fisik yang terbatas, memakai masker saat berada di kantor membuat pegawai tidak sukaberlama-lama dikantor, menyebabkan pegawai sering meninggalkan kantor pada jam kerja. Keadaan ini kemungkinan yang menyebabkan pegawai tidak menerapkan disiplin kerja secara optimal. Pada hasil penelitian ini didapati juga bahwa terdapat $40 \%$ responden yang memiliki disiplin kerja baik dengan kinerja yang baik.

Disiplin adalah sikap, tingkah laku maupun perbuatan yang mengikuti setiap peraturan yang berlaku dalam organisasi, baik peraturan tertulis ataupun tidak tertulis. Disiplin pegawai sangat dibutuhkan dalam organisasi, sebab apa yang menjadi tujuan organisasi akan sukar dicapai tanpa adanya disiplin kerja. Dengan demikian suatu organisasi harus mengusahakan agar setiap pegawainya memiliki disiplin kerja yang tinggi yakni dengan membangun kesadaran para pegawai untuk mematuhi peraturanperaturan yang berlaku, disamping mengupayakan agar peraturan yang ada bersifat jelas, mudah dipahami dan adil. ${ }^{15}$

\section{Hubungan Motivasi dengan Kinerja}

Hubungan antara motivasi dengan kinerja diperoleh nilai $\mathrm{r}=0,632$ dan nilai $\mathrm{p}<0,05$. Hal ini menunjukkan bahwa hubungan antara motivasi dengan kinerja mempunyai hubungan yang kuat dan berpola positif, jika motivasi kerja meningkat maka akan diikuti dengan peningkatan kinerja pegawai atau sebaliknya. Selain itu ditemukan ada hubungan bermakna antara motivasi dengan kinerja.

Hasil penelitian menunjukkan bahwa lebih dari separuh responden (64\%) mempunyai motivasi kerja baik. Indikator kebutuhan memperluas pergaulan dengan dimensi semangat untuk bisa bekerjasama, selalu menghormati pimpinan dan semangat berafiliasi dengan lingkungan merupakan dimensi yang memperoleh nilai tertinggi. Hal ini terlihat sebagaimana disitribusi frekuensi jawaban responden atas pertanyaan-pertanyaan tersebut yang pada umumnya menjawab sering dan selalu. Pada hasil penelitian ini juga didapatkan bahwa terdapat $32 \%$ responden yang berpendapat bahwa pemberian penghargaan (reward) bagi pegawai yang menampilkan prestasi kerja yang tinggi, jarang dilakukan dan pendapat ini pada umumnya disampaikan oleh pegawai yang mempunyai motivasi kerja yang cukup. Pemberian penghargaan bagi pegawai yang berprestasi melalui kegiatan perayaan hari besar nasional di rumah sakit memang pada era new normal ini tidak lagi dilaksanakan, pelatihan-pelatihan diluar rumah sakit yang juga sebagai bentuk penghargaan kepada pegawai tidak lagi dilakukan pada era new normal ini. Hal ini kemungkinan merupakan salah satu penyebab masih terdapat $36 \%$ pegawai yang memiliki motivasi kerja yang cukup.

Motivasi adalah pemberian daya penggerak yang menciptakan semangat kerja seseorang, agar mau bekerjasama, bekerja efektif, dan terintegrasi dengan segala daya upayanya untuk mencapai kepuasan. ${ }^{16}$ Seorang pegawai walaupun hanya memiliki sedikit semangat, tetap punya kontribusi terhadap kinerja. Pegawai mempunyai motivasi berprestasi tinggi akan mencapai prestasi yang tinggi, dan sebaliknya pegawai yang kinerjanya rendah dikarenakan motivasi kerjanya rendah. Pegawai dapat bekerja secara profesional karena pada dirinya terdapat motivasi yang tinggi. Pegawai yang memiliki motivasi yang tinggi biasanya akan melaksanakan tugasnya dengan penuh semangat dan energik karena ada motif-motif dan tujuan tertentu yang melatarbelakangi tindakan tersebut. Motif itulah sebagai faktor pendorong yang memberi kekuatan kepadanya, sehingga ia mau dan rela bekerja keras. Pegawai yang berprestasi tinggi menyukai informasi sebagai umpan balik, karena selalu terdorong untuk memperbaiki dan meningkatkan kegiatannya dalam bekerja, dengan demikian peluangnya untuk meningkatkan prestasi kerja akan lebih besar. ${ }^{17}$

\section{Hubungan Gaya Kepemimpinan dengan Kinerja}

Hubungan antara gaya kepemimpinan dengan kinerja diperoleh nilai $r=0,467$ dan nilai $\mathrm{p}<0,05$. Hal ini menunjukkan bahwa hubungan antara gaya kepemimpinan dengan kinerja mempunyai hubungan yang sedang dan berpola positif serta menunjukkan adanya hubungan bermakna antara gaya kepemimpinan dengan kinerja. Hasil penelitian ini menunjukkan bahwa semakin baik gaya kepemimpinan maka akan diikuti oleh kinerja yang semakin baik atau sebaliknya.

Hasil penelitian menunjukkan bahwa sebagian besar responden (58\%) menyatakan bahwa gaya kepemimpinan termasuk pada kategori baik. Hal ini sejalan dengan jawaban responden atas variabel gaya kepemimpinan yang sebagian besar menjawab selalu dan sering pada setiap pertanyaan. Gaya kepemimpinan inisiatif struktur maupun konsiderasi memperoleh nilai rata-rata yang hampir sama. Gaya kepemimpinan yang merujuk pada perilaku saling percaya, memiliki kepedulian yang tinggi, dan selalu mendorong staf untuk mencapai tujuan organisasi merupakan dimensi gaya kepemimpinan yang memperoleh nilai tertinggi. Gaya kepemimpinan adalah pola perilaku yang diperankan pemimpin secara konsisten untuk mempengaruhi orang lain. ${ }^{18}$ Gaya kepemimpinan yang diterapkan oleh pemimpin dalam suatu organisasi haruslah tepat yakni dengan memperhatikan kemampuan bawahan yang ia pimpin sehingga terjadi keselarasan persepsi di antara pemimpin yang akan mempengaruhi serta staf/pegawai yang akan dipengaruhi, sebab tujuan organisasi akan dapat dicapai ketika dalam melaksanakan pekerjaan ada keselarasan antara pemimpin dan staf yang ia pimpin. Gaya kepemimpinan memegang peranan penting dalam suatu organisasi, pemimpin yang merupakan motor penggerak utama dalam organisasi harus mampu menerapkan gaya kepemimpinan yang tepat agar orang yang ia pimpin akan dengan sukarela melakukan apa yang diharapkan pemimpin, dan dengan demikian tujuan organisasi bisa tercapai.

\section{Hubungan Lingkungan Kerja dengan Kinerja}

Hubungan antara lingkungan kerja dengan kinerja diperoleh nilai $\mathrm{r}=0,535$ dan nilai $\mathrm{p}<0,05$. Hal ini menunjukkan bahwa hubungan antara lingkungan kerja dengan kinerja mempunyai hubungan yang sedang dan berpola positif, artinya semakin baik lingkungan kerja maka akan diikuti oleh kinerja yang semakin baik atau sebaliknya. Selain itu ditemukan 
bahwa adanya hubungan bermakna antara lingkungan kerja dengan kinerja.

Hasil analisis data untuk mengetahui kondisi lingkungan kerja, menunjukkan lebih dari separuh responden (54\%) menyatakan lingkungan kerja yang ada sudah dalam kategori baik. Hal ini terlihat dari jawaban responden dan penilaian atasan langsung yang pada umumnya menjawab setuju dan sangat setuju terkait indikator lingkungan kerja fisik seperti kondisi tempat kerja yang aman dan bersih, serta lingkungan kerja non fisik dengan dimensi hubungan kerja yang baik antar staf dan hubungan yang baik dengan atasan. Meskipun sebagian besar responden menyatakan lingkungan kerja sudah termasuk dalam kategori baik, namun terdapat $24 \%$ responden yang berpendapat bahwa fasilitas yang ada di rumah sakit belum memadai dalam menunjang pelaksanaan tugas.

Lingkungan kerja adalah segala sesuatu yang ada di sekitar para pekerja dan yang dapat mempengaruhi dirinya dalam menjalankan tugas-tugas yang dibebankan, seperti kebersihan, kebisingan, alat perlengkapan kerja, temperatur, kelembapan, polusi, udara, ventilasi. ${ }^{19}$ Kondisi lingkungan kerja dapat dikatakan baik jika memungkinkan seseorang untuk meningkatkan produktifitas kerjanya, baik kondisi fisik maupun psikologis. Kondisi lingkungan kerja yang kondusif dapat meningkatkan semangat kerja pegawai sehingga produktifitas dan kinerja meningkat.

\section{Kinerja Pegawai Administrasi}

Hasil penelitian menunjukkan bahwa separuh dari responden (50\%) memiliki kinerja yang baik. Responden pada umumnya menjawab sering dan selalu terkait pertanyaan bekerja sesuai standar kerja yang telah ditetapkan di era new normal, dan atasan langsung pada umumnya juga menjawab sering terkait pertanyaan tersebut. Hal ini berarti bahwa sebagian besar responden telah melaksanakan pekerjaan sesuai dengan standar operasional prosedur yang telah ditetapkan oleh rumah sakit. Ditemukan juga bahwa sebagian besar responden bersikap jujur dalam melaksanakan tugas dan tanggung jawabnya serta pencapaian output pekerjaan sesuai dengan yang telah ditargetkan. Meskipun sebagian dari responden telah memiliki kinerja yang baik (50\%), namun itu belum optimal karena masih ada sebagian dari responden yang memiliki kinerja cukup (48\%) bahkan ada $2 \%$ yang memiliki kinerja kurang. Pada distribusi frekuensi jawaban responden serta penilaian atasan langsung, ditemukan indikator dengan perolehan nilai terkecil yakni pada indikator perilaku kerja (disiplin) dan hasil kerja (efisiensi dalam melaksanakan tugas). Pada era new normal ini setiap pegawai berupaya untuk bekerja dengan baik sebagaimana kondisi normal seperti sebelumnya, namun kondisi saat ini tidak sepenuhnya menjadi normal karena masih harus berhadapan dengan Covid-19. Reaksi psikologis seperti kecemasan pada masa pandemi ini tidak hanya dirasakan oleh orang awam saja tetapi juga dirasakan oleh pegawai yang bertugas di rumah sakit termasuk didalamnya pegawai non medis. ${ }^{20}$ Selain itu di era new normal interaksi antar pegawai terbatas karena harus menjaga jarak, menghindari kerumunan, mengurangi mobilitas, menyebabkan fungsi sosial terganggu karena ruang untuk bekerja kelompok, saling memberi dukungan saat ada masalah dalam pekerjaan menjadi sangat terbatas, sementara manusia merupakan makhluk sosial yang membutuhkan hal-hal demikian. Harus menggunakan masker sepanjang hari dalam bekerja membuat pegawai merasa kurang nyaman dalam bekerja dan menurunkan semangat kerja. Kondisi ini kemungkinan menjadi penyebab pegawai kurang optimal dalam bekerja di era new normal ini.

Kinerja adalah hasil kerja dalam hal kualitas ataupun kuantitas yang dicapai oleh seseorang atau tim kerja sehubungan dengan pelaksanaan tugas sebagaimana tanggung jawab yang diberikan oleh organisasi. Kemajuan suatu organisasi sangat bergantung pada hasil kerja pegawai yang ada didalamnya. Ketika kinerja yang dihasilkan mampu mencapai ataupun melampaui standar atau target yang telah ditentukan maka kinerja pegawai tersebut dapat dikatakan baik. ${ }^{18}$

\section{Variabel yang Paling Berpengaruh Terhadap Kinerja}

Faktor yang paling berpengaruh terhadap kinerja pegawai administrasi RSUP
Ratatotok Buyat yaitu variabel disiplin kerja $(B=0,520)$. Selain itu, diperoleh nilai Rsquare sebesar 0,661 yang berarti disiplin kerja, motivasi kerja, gaya kepemimpinan dan lingkungan kerja berpengaruh sebesar $66,1 \%$ terhadap kinerja. Kedisiplinan merupakan fungsi operatif manajemen sumber daya manusia yang terpenting karena semakin baik disiplin pegawai maka akan semakin tinggi prestasi kerja yang dicapainya. Tanpa disiplin pegawai yang baik, sulit bagi organisasi mencapai hasil yang optimal. Hasil penelitian ini sejalan dengan teori dari Sinambela yang menyatakan bahwa banyak variabel yang memiliki hubungan signifikan dengan kinerja, tetapi disiplin kerja merupakan faktor penyumbang utama kinerja, sebab disiplin yang baik merupakan cerminan tanggung jawab pegawai atas tugasnya dan hal ini mendorong pegawai untuk semangat dalam bekerja dan hal itu bermanfaat untuk mencapai tujuan organisasi. ${ }^{21}$ Penelitian ini sama dengan hasil penelitian dari Negara mengenai pengaruh motivasi dan disiplin kerja terhadap kinerja karyawan pada rumah sakit Dian Husada Mojokerto. Hasil penelitian menemukan bahwa disiplin merupakan variabel yang berpengaruh paling dominan terhadap kinerja karyawan. ${ }^{22}$ Sejalan dengan itu Susanto dan Veronica dalam penelitiannya tentang pengaruh kepemimpinan, komunikasi dan disiplin terhadap kinerja pegawai non medis di Rumah Sakit Umum Daerah Siti Aisyah Lubuklinggau menunjukkan bahwa disiplin merupakan faktor yang paling berpengaruh terhadap kinerja pegawai. Tolok ukur keberhasilan dalam pelayanan/pekerjaan yaitu disiplin kerja pegawai. Pegawai yang memiliki disiplin kerja yang baik akan mampu bekerja dengan baik walaupun tanpa pengawasan atasan dan tidak melakukan hal-hal yang tidak berkaitan dengan pekerjaan pada saat jam kerja serta mentaati peraturan yang ada tanpa ada rasa paksaan. ${ }^{23}$

Faktor-faktor yang mempengaruhi kinerja pegawai yaitu faktor internal dan eksternal. Faktor internal yang meliputi kemampuan intelektualitas, disiplin kerja, kepuasan kerja, dan motivasi. Faktor eksternal yang meliputi gaya kepemimpinan, lingkungan kerja, kompensasi, dan sistem manajemen 
kinerja. Selanjutnya, kinerja dapat diukur dengan indikator yaitu hasil kerja, perilaku kerja dan sifat pribadi. Hasil kerja seperti kualitas hasil kerja (mutu hasil kerja), kuantitas hasil kerja (banyaknya/jumlah hasil kerja), efisiensi dalam melaksanakan tugas (kemampuan seseorang dalam melaksanakan tugas secara baik dan tepat yakni tidak membuang waktu, biaya dan tenaga). Perilaku kerja seperti disiplin kerja (kemampuan kerja individu untuk secara teratur, bekerja dengan tekun secara terus-menerus berdasarkan aturan-aturan yang ada dan tidak melanggar aturanaturan tersebut), inisiatif (prakarsa) dan ketelitian (kecermatan). Sifat pribadi seperti kejujuran dan kreativitas. ${ }^{18}$

\section{KESIMPULAN}

Kesimpulan penelitian ini yaitu terdapat hubungan bemakna dan positif antara faktor disiplin kerja, motivasi kerja dan lingkungan kerja dengan kinerja pegawai administrasi RSUP Ratatotok Buyat di era new normal, dan disiplin kerja merupakan faktor yang paling berpengaruh terhadap kinerja pegawai. Berdasarkan hal tersebut maka dibutuhkan upaya meningkatkan disiplin kerja, motivasi kerja, gaya kepemimpinan dan lingkungan kerja di RSUP Ratatotok Buyat.

\section{KONTRIBUSI PENULIS}

Seluruh penulis berkontribusi secara merata dalam pelaksanaan penelitian dan penulisan naskah ini.

\section{KONSIDERASI ETIK}

Penelitian ini telah disetujui oleh Komisi Etik Rumah Sakit Umum Pusat Ratatotok Buyat.

\section{PENDANAAN}

Seluruh penulis mengklaim tidak ada pendanaan eksternal ataupun hibah terkait dengan penelitian ini.

\section{KONFLIK KEPENTINGAN}

Seluruh penulis menyatakan tidak ada konflik kepentingan dalam pelaksanaan penelitian maupun publikasi artikel ini.

\section{DAFTAR PUSTAKA}

1. Pemerintah Indonesia. Undang-Undang Republik Indonesia nomor 44 tahun 2009 tentang Rumah Sakit. Indonesia; 2009 p. 65.

2. Chairani. Pengaruh motivasi, disiplin kerja dan pengembangan karir terhadap kinerja pegawai negeri sipil pada unit pelaksana teknis Badan Pendapatan Daerah Palembang I. Universitas Tridinanti Palembang; 2020.

3. Ariadharma. Faktor-faktor yang mempengaruhi kinerja pegawai di bagian administrasi keuangan dan pelayanan pada Rumah Sakit Umum Daerah Pelalawan. Pekbis J. 2020;12(2):95-105.

4. Hayati N, Agustian DD, Avriyanti S. Pengaruh kompensasi dan disiplin terhadap kinerja pegawai Rumah Sakit Pertamina Tanjung Tabalong. J Adm Publik dan Adm Bisnis. 2019;2(1):174-93.

5. Ali K, Agustian DD. Analisis pengaruh budaya organisasi dan gaya kepemimpinan terhadap kepuasan kerja untuk meningkatkan kinerja karyawan di Rumah Sakit Muhammadiyah Metro. Deriv J Manaj. 2018;12(2):7-15.

6. Pamungkas AS, Widowati SY. Pengaruh kepemimpinan, lingkungan kerja dan disiplin kerja terhadap kinerja karyawan. Maj Imliah Solusi. 2020;18(3):147-60.

7. Hulwani TZ, Damayanti Y, Manurung K, Andriani D, Ithing. Hubungan kompensasi dan disiplin dengan kinerja perawat unit pelayanan khusus di Rumah Sakit Umum Daerah Kota Langsa. J Kesehat Kebidanan. 2021;10(2):10417.

8. Indriyani R, Wijayaningsih R, Soehardi. Pengaruh gaya kepemimpinan dan disiplin kerja terhadap kinerja karyawan Rumah Sakit Taman Harapan Baru Bekasi. J Ilm Manaj Ubhara. 2021;3(1):228-37.

9. Ariko R, Sumarni T. Hubungan motivasi dengan kinerja perawat di ruang rawat inap RSUD Ajibarang. J Ilmu Kesehat UMC. 2021;10(1):12-9.

10. Kusno FA, Porotu’o J, Umboh J. Faktor-faktor yang berhubungan dengan kinerja perawat di ruang rawat inap interna UPTD RSUD Bitung. J Paradig Sehat. 2019;7(3):15-31.
11. Arsita ANM, Sriatmi A, Kusumastuti W. Faktorfaktor yang berhubungan dengan kinerja perawat di unit rawat inap Rumah Sakit Umum Daerah Ungaran Kabupaten Semarang. Media Kesehat Masy Indones. 2020;19(4):255-62.

12. Taringan SP, Simanjorang A, Megawati. Faktorfaktor yang mempengaruhi kinerja perawat Rumah Sakit Pabatu di Serdang Berdagai. J Komunitas Kesehat. 2020;2(1):48-55.

13. Susanto Y. Integritas auditor pengaruhnya dengan kualitas hasil audit. Edisi Pert. Yogyakarta: Deepublish Yogyakarta; 2020. 152 p.

14. Muamarizal S, Samsir, Marzolina. Pengaruh pengalaman kerja dan penilaian prestasi kerja terhadap pengembangan karir karyawan pada PT Jasaraharja Putera Cabang Pekanbaru. JOM FEKON. 2015;2(1):1-21.

15. Sutrisno HE. Manajemen sumber daya manusia. Edisi Pert. Jakarta: Prenadamedia grup Jakarta; 2019. $244 \mathrm{p}$

16. Hamali AY. Pemahaman manajemen sumber daya manusia, strategi mengelola karyawan. Cetakan Pe. Yogyakarta: CAPS (Center for Academic Publishing Service) Yogyakarta; 2016. 273 p.

17. Wahyudi M. Pengaruh Disiplin Dan Motivasi Terhadap Kinerja Karyawan. Sci J Reflect Econ Accounting, Manag Bus. 2019;2(3):351-60.

18. Busro M. Teori-teori manajemen sumber daya manusia. Edisi Pert. Jakarta: Prenadamedia grup Jakarta; 2018.375 p.

19. Siagian SP. Manajemen sumber daya manusia. Edisi Pert. Jakarta: PT Bumi Aksara Jakarta; 2015.

20. Agung IM. Memahami pandemi Covid-19 dalam perspektif psikologi sosial. Bul Ilm Psikol. 2020;1(2):68-84.

21. Sinambela LP. Manajemen sumber daya manusia, membangun tim kerja yang solid untuk meningkatkan kinerja. Cetakan Ke. Jakarta: PT Bumi Aksara Jakarta; 2019. 613 p.

22. Negara NB. Pengaruh motivasi dan disiplin kerja terhadap kinerja karyawan pada Rumah Sakit Dian Husada Mojokerto. Universitas Muhammadiyah Malang; 2021.

23. Susanto Y, E V. Pengaruh kepemimpinan, komunikasi dan disiplin terhadap kinerja pegawai nonmedis RSUD Siti Aisyah Lubuklinggau. J Manaj dan Bisnis Sriwij. 2019;17(1):32-40.

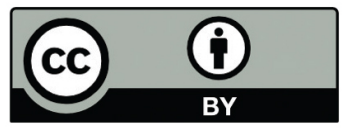

This work is licensed under a Creative Commons Attribution 